\title{
Implementasi Strategi Think-Talk-Write (TTW) pada Pembelajaran Menulis dan Pemahaman Matematis
}

\author{
Sri Kadarwati \\ Nining Sulistyaningsih \\ Edi Prayitno \\ Bambang Yulianto \\ UPBJJ-UT Semarang \\ Jalan. Kelud Utara III, Semarang
}

\begin{abstract}
This study examines whether students' ability in mathematical writing and understanding gained from teaching through think talk write' strategy is better than students' ability gained from conventional one. This study also examines students' ability in mathematical writing and understanding from gender aspects. Using quantitative design, data was taken through documentary study, questioner sheets and observation. Data was analyzed using two ways ANOVA. Result shows: a) the ability of students in mathematical writing and understanding gained from teaching using think talk write' strategy is better than the ability gained from conventional one; b) ) the ability of female students is better than male students; and c) Think Talk Write strategy can improve students' mathematical disposition ability.
\end{abstract}

Key Words: mathematical understanding, mathematical writing ability, think talk write strategy

Hasil Ujian Nasional (UN) tahun 2008 untuk mata pelajaran matematika di SMP 32 Semarang masih di bawah mata pelajaran lain. Banyak faktor yang menyebabkan matematika dianggap pelajaran sulit, salah satunya adalah karakterisitik materi matematika yang bersifat abstrak, logis, sistematis, dan penuh dengan lambang-lambang dan rumus. Rendahnya kemampuan menginterpretasi informasi matematis menyebabkan rendahnya kemampuan memberikan respon matematis. Kemampuan menginterpretasi dan memberikan respon, atau yang biasa kita sebut kemampuan komunikasi matematis inilah yang perlu ditumbuhkembangkan pada diri siswa.

Setelah kemampuan komunikasi matematis dikuasai dan terinternalisasi dalam diri dan sikap siswa, kemampuan tersebut menurut Syaban (2008) dapat mengembangkan sikap kritis, cermat, obyektif dan terbuka, menghargai keindahan matematika, serta rasa ingin tahu dan senang belajar matematika. Kebiasaan matematis tersebut dapat mendorong tumbuhnya sikap menerima dan menyenangi matematika atau yang disebut disposisi matematis. Disposisi matematis sebagai suatu kecenderungan untuk berpikir dan bertindak dengan cara-cara yang positif. Kecenderungan ini ditunjukkan oleh minat dan rasa percaya diri dalam menyelesaikan tugas matematika, kesediaan untuk mencoba alternatif penyelesaian yang ditemui dan tekun dalam menyelesaikan permasalahan matematis, serta kesediaan untuk melakukan refleksi saat mempelajari matematika (Anku, 1996).

Pembelajaran matematika yang menekankan pada kegiatan menulis matematis dapat digunakan sebagai sarana untuk melatih siswa dalam mengungkapkan gagasan matematis secara tertulis. Menulis dapat digunakan sebagai sarana untuk membantu memudahkan siswa mengaitkan pengetahuan yang dimiliki dengan pengetahuan baru yang sedang dipelajari. Oleh karena itu pembelajaran matematika di sekolah diharapkan dapat mendorong meningkatkan kemampuan menulis dan pemahaman matematis siswa. 
Salah satu strategi pembelajaran matematika yang diduga dapat meningkatkan kemampuan menulis dan pemahaman matematis adalah strategi Think-Talk-Write (TTW). Strategi TTW ini diawali dengan bagaimana siswa memikirkan materi yang telah dipersiapkan oleh guru, membangun dan mengorganisasikan ide-ide dari apa yang telah dibaca (tahap think). Kemudian apa yang telah dibangun dalam pemikiran siswa didiskusikan untuk merefleksi ide-ide yang telah disepakati (tahap talk). Dan akhirnya siswa menuliskan rangkuman dari hasil diskusi dengan bahasa mereka sendiri (tahap write).

Keterampilan menulis antara anak laki-laki dan perempuan berbeda. Hal ini dikarenakan struktur anatomi otak manusia antara laki-laki dan perempuan berbeda (Folia, 2008), sehingga kesenjangan gender dalam ilmu matematika menjadi bahan riset yang menarik untuk diteliti. Merujuk pada uraian di atas, permasalahan dalam penelitian ini adalah apakah pembelajaran yang menerapkan strategi Think-Talk-Write (TTW) dapat menumbuh kembangkan kemampuan menulis dan pemahaman matematis siswa SMP? Permasalahan ini dirinci ke dalam pertanyaan sebagai berikut:

1. Apakah kemampuan menulis matematis siswa SMP yang memperoleh pembelajaran matematika dengan strategi TTW lebih baik daripada dengan metode peragaan disertai penugasan?

2. Apakah pemahaman matematis siswa SMP yang memperoleh pembelajaran matematika dengan strategi TTW lebih baik daripada dengan metode peragaan disertai penugasan ?

3. Apakah kemampuan menulis matematis siswa SMP perempuan yang memperoleh pembelajaran matematika dengan strategi TTW lebih baik daripada siswa laki-laki?

4. Apakah pemahaman matematis siswa SMP perempuan yang memperoleh pembelajaran matematika dengan strategi TTW lebih baik daripada siswa laki-laki?

5. Sejauhmana pembelajaran dengan strategi TTW mendukung disposisi matematis siswa SMP?

Untuk memfokuskan arah penelitian ini, peneliti membatasi cakupan permasalahan pada hal-hal berikut ini,

1. Subjek penelitian adalah siswa kelas VII SMP Negeri 32 Semarang semester dua tahun ajaran 2008/2009.

2. Materi pembelajaran dibatasi pada: mengidentifikasi sifat-sifat persegi panjang, persegi, trapesium, jajaran genjang, belah ketupat dan layang-layang, keliling dan luas bangun segiempat tersebut serta menggunakannya dalam pemecahan masalah.

Tujuan penelitian ini adalah sebagai berikut,

1. Untuk mengetahui apakah kemampuan menulis matematis siswa SMP yang memperoleh pembelajaran matematika dengan strategi TTW lebih baik daripada dengan metode peragaan disertai peragaan.

2. Untuk mengetahui apakah pemahaman matematis siswa SMP yang memperoleh pembelajaran matematika dengan strategi TTW lebih baik daripada dengan metode peragaan disertai penugasan.

3. Untuk mengetahui apakah kemampuan menulis matematis siswa SMP perempuan yang memperoleh pembelajaran matematika dengan strategi TTW lebih baik daripada siswa laki-laki.

4. Untuk mengetahui apakah pemahaman matematis siswa SMP perempuan yang memperoleh pembelajaran matematika dengan strategi TTW lebih baik daripada siswa laki-laki.

5. Sejauhmana pembelajaran dengan strategi TTW dapat mendukung disposisi matematis siswa SMP. 
Komunikasi matematis, baik tertulis maupun lisan merupakan teropong untuk memandang karya matematis seseorang (Reiter, 1995). Mengkomunikasikan gagasan baik secara lisan maupun tertulis dapat mengarah pada refleksi terhadap pemahaman, klarifikasi gagasan baru dan keinginan untuk mempelajari lebih banyak konsep dan kosa kata baru. Pengungkapan gagasan matematis akan memberi pengalaman yang lebih kaya dan lebih memperkaya wawasan siswa, serta membuahkan teknik penjelasan dan teknik bertanya yang lebih baik (Annenberg Media, 1997-2009).

Menulis adalah suatu proses alami, suatu metode komunikasi antara dua orang dan suatu cara mengungkapkan pikiran dan perasaan yang muncul dalam diri seseorang (Burchfield,; Jorgensen; McDowell; \& Rahn, 1993). Menulis matematis bukan untuk menunjukkan bahwa tugas telah diselesaikan, namun dimaksudkan untuk menunjukkan seberapa baik pemahaman seseorang tentang gagasan dan konsep-konsep matematika (Lee, 2004). Aktivitas menulis matematis dapat dilakukan melalui representasi matematis (Ansari, 2003). Ada tiga kategori dalam representasi matematis, yaitu: (a) aspek drawing, yakni memunculkan model konsep, seperti gambar, diagram, tabel, dan grafik; (b) aspek mathematical expressions, yakni membentuk model matematis; dan (c) aspek written text, yakni argumentasi verbal yang didasarkan pada gambar dan konsep-konsep formal.

Pemahaman matematis merupakan faktor yang berpengaruh terhadap kemampuan matematis yang lain, misalnya kemampuan komunikasi, kemampuan penalaran, dan kemampuan pemecahan masalah. Menurut taksonomi Bloom, pemahaman matematis merupakan aspek mendasar dan diperlukan untuk dapat melangkah ke tingkat selanjutnya. Pemahaman menurut Taxonomy Bloom terdiri atas enam kategori yang terdiri atas: (1) remember, (2) understand, (3) apply, (4) analyze, (5) evaluate, dan (6) create (Anderson dan Krathwohl, 2001). Kemampuan pemahaman matematis siswa SMP meliputi pemahaman konsep, penalaran dan komunikasi, serta pemecahan masalah (Depdiknas, 2007). Pemahaman matematis dalam penelitian ini adalah tingkat atau level pengetahuan siswa tentang konsep, prinsip, algoritma dan kemahiran siswa menggunakan strategi penyelesaian terhadap soal atau masalah yang disajikan.

Biasanya anak perempuan lebih rajin dalam menulis dan anak laki-laki lebih kuat pada logika. Pandangan yang demikian ini disebut bias gender. Istilah gender pertama kali diperkenalkan oleh Robert Stoller pada tahun 1968 (PGRI, 2006) untuk memisahkan pencirian manusia yang didasarkan pada pendefinisian yang bersifat sosial budaya dengan ciri-ciri fisik biologis. Terkait dengan bias gender dalam pendidikan matematika, terdapat perbedaan anatomi otak laki-laki dan perempuan. Dalam berkomunikasi, pertama kali mendapat informasi dan dalam menghadapi suatu permasalahan, laki-laki akan berkecenderungan untuk menggunakan logika (wilayah otak kiri lebih dominan), sedangkan perempuan cenderung menggunakan perasaan penggunaan otak kanan lebih dominan) (Folia, 2008).

Untuk memfasilitasi siswa berlatih menulis matematis salah satunya dengan menggunakan strategi TTW. Strategi TTW yang dikenalkan oleh Huinker dan Laughlin (1996) pada dasarnya dibangun melalui kegiatan berpikir, berbicara dan menulis. TTW adalah suatu strategi yang memfasilitasi pengungkapan bahasa lisan dan kegiatan menulis. TTW membantu para siswa dalam mengumpulkan dan mengembangkan gagasan melalui percakapan terstruktur (Anonim, 1999). Arnawa (2008) dalam penelitiannya melaporkan bahwa pembelajaran dengan strategi Think-Talk-Write (TTW) memberikan kesempatan kepada siswa untuk terlibat aktif dalam pembelajaran melalui kegiatan berpikir, merefleksikan dan menyusun ide-ide, serta menguji ideide itu sebelum memulai menulisnya. Hal ini senada dengan Huinker dan Laughlin (1996: 88) yang menyatakan bahwa strategi TTW memungkinkan semua siswa mengungkapkan ide yang melatarbelakangi gagasan mereka sebelum mereka menuliskannya. 


\section{METODOLOGI}

Penelitian ini bersifat eksperimen menggunakan desain "pre test - post test group design". Adapun alasan menggunakan pendekatan eksperimen (eksperimental research) dalam upaya memperoleh jawaban dari pertanyaan penelitian dan pencapaian tujuan penelitian. Perlakuan yang dilakukan terhadap variabel bebas (strategi pembelajaran) akan dilihat hasilnya pada variabel terikat. Desain eksperimen menggunakan Anova Dua-Jalur dengan faktorial $2 \times 2$.

Populasi dalam penelitian ini adalah siswa kelas VII SMP Negeri 32 Semarang pada semester genap tahun pelajaran $2008 / 2009$. Jumlah siswa 235 orang yang terbagi dalam enam kelas. Pembagian kelas dilaksanakan pada awal tahun pelajaran berdasarkan pemerataan, sehingga tidak ada kelas unggulan.

Pengambilan sampel dilakukan dengan cara cluster random sampling yaitu dengan melakukan pengambilan secara acak siswa yang berada dalam 2 kelas dari 6 kelas. Dari hasil pengundian diperoleh siswa kelas VIIA sebagai kelas eksperimen dan siswa kelas VIIB sebagai kelas kontrol. Selanjutnya untuk keperluan penelitian pada setiap kelas dipilih secara acak sebagai subjek penelitian sebanyak 15 siswa laki-laki dan 15 siswa perempuan. Siswa yang tidak terpilih sebagai subjek penelitian tetap mengikuti pembelajaran tetapi datanya tidak digunakan. Variabel penelitian ini adalah: pembelajaran matematika menggunakan strategi TTW sebagai variabel bebas; kemampuan menulis rangkuman dan pemahaman matematis sebagai variabel terikat.

Instrumen yang digunakan dalam penelitian ini meliputi: (a) tes; (b) angket disposisi matematis; dan (c) lembar observasi. Instrumen tes dalam penelitian ini terdiri dari tes kemampuan menulis rangkuman dan tes pemahaman matematis. Tes menulis rangkuman ini untuk mengungkap kemampuan menulis rangkuman dari materi yang disajikan sejumlah 6-10 lembar. Kriteria penilaian untuk tes kemampuan menulis rangkuman matematika meliputi kejelasan penulisan judul, kejelasan penulisan materi pokok, kejelasan penulisan tujuan pembelajaran, dan kejelasan penulisan isi materi yang meliputi aspek drawing, aspek written texts dan aspek mathematical expression. Ketiga aspek ini merupakan bagian dalam mengungkap kemampuan menulis matematis (Ansari, 2003). Untuk menilai tes menulis rangkuman ini digunakan rubrik skoring (scoring rubrics). Sedangkan untuk tes pemahaman matematis berbentuk uraian sebanyak 8 butir soal dari 10 butir soal yang telah divalidasi.

\section{HASIL DAN PEMBAHASAN}

Rata-rata hasil postes kemampuan menulis rangkuman dan pemahaman matematis disajikan pada Tabel 1 berikut.

Tabel 1. Rata-rata Hasil Postes Kemampuan Menulis Rangkuman dan Pemahaman Matematis Materi Pokok Segiempat

\begin{tabular}{lccc}
\hline \multirow{3}{*}{ Gender } & \multicolumn{3}{c}{ Kemampuan Menulis Rangkuman } \\
\cline { 2 - 4 } & \multicolumn{3}{c}{ Pemahaman Matematis } \\
\cline { 2 - 4 } & Kelas Eksperimen & Kelas Kontrol & Rata-rata \\
\cline { 2 - 4 } Laki-laki & 78,6 & 73,7 & 76,1 \\
& 76,5 & 72,3 & 76,3 \\
\hline \multirow{2}{*}{ Perempuan } & 83,5 & 78,9 & 81,2 \\
& 83,9 & 77,8 & 80,8 \\
\hline \multirow{2}{*}{ Rata-rata } & 81,0 & 76,3 & \\
& 80,2 & 75,1 & \\
\hline
\end{tabular}


Adapun hasil Uji Statistik Anova Dua Jalur untuk Postes Kemampuan Menulis Rangkuman dan Pemahaman Matematis Materi Pokok Segiempat disajikan pada tabel 2 berikut.

Tabel 2. Hasil uji statistik Anova Dua Jalur untuk Postes Kemampuan Menulis Rangkuman dan Pemahaman Matematis Materi Pokok Segiempat

\begin{tabular}{|c|c|c|c|c|}
\hline ANOVA & \multicolumn{4}{|c|}{$F_{\text {hitung }}$} \\
\hline$F_{\text {tabel }}=4,02$ & \multicolumn{2}{|c|}{ KM } & \multicolumn{2}{|c|}{ PM } \\
\hline Model Pembelajaran & \multicolumn{2}{|c|}{4,62} & \multicolumn{2}{|c|}{4,38} \\
\hline Eksperimen vs Kontrol & 81,0 & 76,3 & 80,2 & 75,1 \\
\hline Gender & \multicolumn{2}{|c|}{5,15} & \multicolumn{2}{|c|}{6,86} \\
\hline Laki-laki vs Perempuan & 76,1 & 81,2 & 74,4 & 80,8 \\
\hline
\end{tabular}

Untuk mengetahui besar hubungan kemampuan menulis rangkuman dengan pemahaman matematis digunakan perhitungan korelasi melalui SPSS Versi 15 dengan nilai Pearson Correlation 0,802 . Ini berarti kemampuan menulis rangkuman saling mempengaruhi dengan pemahaman matematis sebesar $80,2 \%$ dan $19,8 \%$ dipengaruhi oleh faktor yang lain. Berdasarkan hasil penskoran tugas latihan menulis rangkuman dan refleksi pembelajaran matematika pada kelas eksperimen pada setiap pertemuan diperoleh data rata-rata skornya adalah 68,$3 ; 73,7 ; 77,5 ; 82,4$; dan 84,3 .

Perkembangan kemampuan menulis rangkuman diikuti dengan perkembangan pemahaman matematis siswa. Selain menulis rangkuman, di akhir pembelajaran juga diadakan evaluasi pemahaman matematis untuk mengukur pencapaian indikator pembelajaran, selama 10 15 menit. Adapun hasilnya adalah 65,$3 ; 70,5 ; 77,5 ; 80,4 ; 83,3 ;$ dan 84,8 .

Hasil angket terhadap pendapat siswa terhadap disposisi matematis disajikan dalam Tabel 3 berikut.

Tabel 3. Rekap Hasil Angket Disposisi Matematis

\begin{tabular}{|c|c|c|c|c|}
\hline \multirow{2}{*}{ Pernyataan } & \multicolumn{4}{|c|}{ Persentase } \\
\hline & SS & S & TS & STS \\
\hline Belajar matematika melalui menulis menyenangkan & 24.44 & 63.33 & 12.22 & 0.00 \\
\hline $\begin{array}{l}\text { Saya tertantang untuk lebih banyak mengerjakan tugas- } \\
\text { tugas matematika. }\end{array}$ & 18.89 & 66.67 & 14.44 & 0.00 \\
\hline $\begin{array}{l}\text { Belajar matematika dengan menulis membuat saya tidak } \\
\text { mudah lupa. }\end{array}$ & 23.33 & 72.22 & 4.44 & 0.00 \\
\hline $\begin{array}{l}\text { Merangkum/membuat kesimpulan pembelajaran membuat } \\
\text { saya lebih memahami kegunaan matematika. }\end{array}$ & 34.44 & 55.56 & 10.00 & 0.00 \\
\hline Tugas-tugas menulis membebani saya. & 10.00 & 24.44 & 52.22 & 13.33 \\
\hline Menulis membuat saya malas belajar. & 0.00 & 11.11 & 61.11 & 27.78 \\
\hline Saya lebih suka belajar kelas. & 38.89 & 50.00 & 7.77 & 3.33 \\
\hline $\begin{array}{l}\text { Melalui diskusi kelas dapat membantu memahami materi } \\
\text { pelajaran. }\end{array}$ & 38.89 & 55.56 & 5.55 & 0.00 \\
\hline $\begin{array}{l}\text { Melalui strategi TTW memudahkan dan meyakinkan saya } \\
\text { dalam mengerjakan tugas-tugas (soal). }\end{array}$ & 44.44 & 50.00 & 5.55 & 0.00 \\
\hline $\begin{array}{l}\text { Melalui strategi TTW memudahkan dan meyakinkan saya } \\
\text { dalam memahami matematika dan kegunaannya. }\end{array}$ & 37.78 & 60.00 & 2.22 & 0.00 \\
\hline
\end{tabular}

Keterangan: SS= Sangat Setuju;S= Setuju;TS= Tidak Setuju;STS= Sangat Tidak Setuju.

Pembahasan hasil penelitian ini antara lain meliputi: (1) analisis implementasi pembelajaran dengan strategi TTW terhadap kemampuan menulis dan pemahaman matematis; 
(2) analisis implementasi pembelajaran dengan strategi TTW terhadap kemampuan menulis dan pemahaman matematis dengan faktor gender dan (3) disposisi matematis.

\section{Analisis Implementasi Pembelajaran dengan Strategi TTW terhadap Kemampuan Menulis dan Pemahaman Matematis}

Pembelajaran matematika dengan strategi TTW telah dapat membantu siswa dalam menumbuhkembangkan kemampuan menulis dan pemahaman matematis. Fase-fase dalam strategi yang digunakan pada pembelajaran membimbing siswa untuk mengungkapkan ide-ide matematisnya dan belajar menulis melalui kegiatan merangkum pada akhir pembelajaran. Waktu yang diberikan dalam merangkum ini kurang lebih antara 10-15 menit. Strategi TTW yang diterapkan pada pembelajaran mengarahkan siswa dalam menemukan konsep-konsep matematis.

Think yang disajikan dalam Lembar Aktivitas Siswa (LAS) mendorong siswa untuk menemukan konsep dan rumus matematika melalui hands on activity. Hasil tahap think dibawa ke tahap talk, yaitu diskusi antar anggota kelompok. Guru bertindak sebagai fasilitator, mediator, dan nara sumber untuk membantu siswa menemukan konsep dan rumus matematika (scaffolding). Hasil tahap talk dituliskan pada Lembar Rangkuman Siswa (LRS) dengan bahasa sendiri (tahap write). Pada tahap write, guru membimbing dan memonitor setiap siswa untuk menghindari miskonsepsi. Dengan kegiatan ini siswa benar-benar mengkonstruk pengetahuannya dan bukan pengetahuan yang datang dari guru sesuai pendapat dari Muijs dan Reynolds (2008).

Melalui kegiatan menulis rangkuman ini, guru mengetahui kesalahan yang dibuat siswa dalam memahami konsep, dalam menuliskan rumus, dan dalam membuat gambar bangun datar segiempat yang merupakan materi dalam penelitian ini. Hal ini sesuai dengan pernyataan Masingila dan Winiowska (1996) bahwa aktivitas menulis siswa bagi guru dapat digunakan untuk memantau miskonsepsi siswa terhadap konsep-konsep matematis.

Aktivitas siswa dalam menulis, seperti menulis jawaban soal uraian, menulis kembali konsep, memberikan penjelasan, dan sebagainya memungkinkan guru memantau perkembangan siswa. Dalam penelitian ini kesalahan yang sering dibuat siswa saat merangkum berupa kesalahan penggunaan simbol, tanda baca, dan huruf kapital, penyusunan kalimat yang tidak sempurna, serta dalam menggambar tidak menggunakan penggaris. Secada dalam Mac.Gegor (1999) menyimpulkan bahwa "kecakapan bahasa, berhubungan dengan prestasi dalam matematika. Kegiatan berpikir (think), berbicara (talk) dan menulis rangkuman (write) mendorong siswa memahami konsep-konsep dan menggunakan konsep untuk menyelesaikan tugas.

Pembelajaran sebagaimana telah diuraikan, membuktikan bahwa hasil belajar matematika siswa SMP, yakni kemampuan menulis rangkuman dan pemahaman matematis siswa SMP yang memperoleh pembelajaran matematika dengan strategi TTW mengalami peningkatan setiap pertemuan. Dari hasil perhitungan diperoleh harga koefisien korelasi sebesar 0,802 . Hal ini menunjukan bahwa terdapat hubungan yang tinggi antara kemampuan menulis rangkuman dengan pemahaman matematis. Fakta ini didukung dengan hasil postes antara kemampuan menulis rangkuman dengan pemahaman matematis terjadi hubungan, siswa yang mendapatkan nilai kemampuan menulis rangkuman tinggi, nilai pemahaman matematisnya juga tinggi. Huinker dan Laughlin (1996) menyatakan bahasa dapat membantu siswa untuk bekerja sama antara yang satu dengan yang lain dalam memecahkan masalah dalam matematika. Ini berarti kemampuan menulis rangkuman dapat membantu siswa meningkatkan pemahaman matematisnya.

Dari hasil perhitungan ANOVA dua jalur untuk kemampuan menulis rangkuman, diperoleh $F_{\text {hitung }}=4,62$ dan $F_{\text {tabel }}=4,02$ untuk $a=5 \%$. Karena $F_{\text {hitung }}>F_{\text {tabel }}$ maka $H_{0}$ ditolak. Jadi, 
ada perbedaan yang signifikan kemampuan menulis rangkuman materi segiempat antara siswa SMP yang memperoleh pembelajaran dengan strategi TTW dengan siswa yang memperoleh pembelajaran secara konvensional. Skor rata-rata kemampuan menulis rangkuman materi segiempat siswa SMP yang memperoleh pembelajaran dengan strategi TTW $=81,0$ sedangkan siswa yang memperoleh pembelajaran secara konvensional $=76,3$. Jadi, dapat disimpulkan bahwa kemampuan menulis rangkuman materi segiempat siswa SMP yang memperoleh pembelajaran dengan strategi TTW secara signifikan lebih baik dari pada siswa SMP yang memperoleh pembelajaran dengan metode peragaan disertai penugasan. Adapun perhitungan ANOVA dua jalur untuk pemahaman matematis, diperoleh $F_{\text {hitung }}=4,04$ dan $F_{\text {tabel }}=4,02$ untuk a $=5 \%$. Karena $F_{\text {hitung }}>F_{\text {tabel }}$ maka $\mathrm{H}_{0}$ ditolak. Dengan demikian, ada perbedaan yang signifikan pemahaman matematis materi segiempat antara siswa SMP yang memperoleh pembelajaran menggunakan strategi TTW secara kelas kecil dengan siswa SMP yang memperoleh pembelajaran dengan metode peragaan disertai penugasan.

Skor rata-rata pemahaman matematis materi siswa SMP yang memperoleh pembelajaran dengan strategi TTW $=80,4$ sedangkan siswa yang memperoleh pembelajaran secara konvensional $=75,1$. Jadi, dapat disimpulkan bahwa pemahaman matematis materi segiempat siswa SMP yang memperoleh pembelajaran dengan strategi TTW lebih baik dari pada siswa SMP yang memperoleh pembelajaran dengan metode peragaan disertai penugasan.

\section{Analisis Implementasi Pembelajaran dengan Strategi TTW ditinjau dari Faktor Gender}

Dari hasil ANOVA dua jalur untuk kemampuan menulis rangkuman diperoleh $\mathrm{F}_{\text {hitung }}=$ 5,15 dan $F_{\text {tabel }}=4,02$ untuk $a=5 \%$. Karena $F_{\text {hitung }}>F_{\text {tabel }}$ maka $\mathrm{H}_{0}$ ditolak. Jadi, ada perbedaan yang signifikan kemampuan menulis rangkuman materi segiempat antara siswa SMP berdasarkan gender. Skor rata-rata kemampuan menulis rangkuman materi segiempat siswa SMP laki-laki $=76,1$ sedangkan siswa SMP perempuan $=81,2$. Dengan demikian, dapat disimpulkan bahwa kemampuan menulis rangkuman materi segiempat siswa SMP perempuan secara signifikan lebih baik dari pada siswa laki-laki.

Hasil perhitungan ANOVA dua jalur untuk pemahaman matematis diperoleh $F_{\text {hitung }}=6,43$ dan $F_{\text {tabel }}=4,02$ untuk $a=5 \%$. Karena $F_{\text {hitung }}>F_{\text {tabel }}$ maka $H_{0}$ ditolak. Dengan demikian, ada perbedaan yang signifikan pemahaman matematis materi segiempat antara siswa SMP laki-laki dengan siswa SMP perempuan. Skor rata-rata pemahaman matematis materi segiempat siswa SMP laki-laki $=74,4$ sedangkan siswa SMP perempuan $=80,8$. Jadi dapat disimpulkan bahwa pemahaman matematis materi segiempat siswa SMP perempuan lebih baik daripada siswa lakilaki.

Menurut Brizendine (2006) wanita dapat menggunakan sekitar 20.000 kata tiap harinya, sedangkan pria hanya sekitar 7.000 kata. Teori ini didukung laporan Burmana,2008 tentang hasil penelitian menggunakan alat functional Magnetic Resonance Imaging (fMRI) bahwa bagian otak yang merespon bahasa pada anak perempuan masih menunjukkan aktivasi signifikan lebih besar dari pada anak laki-laki. Sehingga dapat dipahami jika kemampuan menulis rangkuman siswa SMP perempuan hasilnya lebih baik dari pada siswa laki-laki.

Telah disebutkan di atas bahwa terdapat hubungan yang sangat tinggi antara kemampuan menulis rangkuman dan pemahaman matematis. Kemampuan menulis rangkuman siswa perempuan lebih baik dari pada siswa laki-laki, maka pemahaman matematis siswa perempuan juga lebih baik dari pada laki-laki. Hasil riset Sapienza (dalam Rizal, 2008) menyebutkan bahwa para pelajar perempuan ternyata memiliki prestasi kemampuan ilmu matematika yang sebanding bahkan lebih unggul dibandingkan pelajar pria dikarenakan pengaruh dari sumber daya dan kesempatan berkarya dalam tatanan sosio-kultural suatu bangsa. 


\section{Analisis Pembelajaran dengan Strategi TTW terhadap Disposisi Matematis}

Telah diuraikan sebelumnya bahwa disposisi matematis siswa diketahui melalui dua cara yaitu melalui angket dan melalui pengamatan. Melalui pengamatan diperoleh dari observer yaitu guru yang menjadi kolaborator, dan peneliti dapat mengetahui perubahan atau meningkatnya disposisi matematis siswa. Misalnya pada awal penerapan pembelajaran dengan strategi TTW, siswa terlihat masih canggung dan kurang komunikatif. Hal ini dibuktikan dengan pemahaman matematis siswa yang memperoleh pembelajaran dengan strategi TTW skornya adalah 65,3. Selanjutnya terjadi peningkatan perolehan skor pemahaman matematis. Siswa semakin memiliki kepercayaan diri dalam menyelesaikan tugas-tugas matematis. Kerja sama antar kelas mengeksplorasi dan menemukan solusi dari tugas-tugas semakin meningkat. Peningkatan ini ditandai dengan banyaknya variasi jawaban siswa pada saat diskusi. Siswa juga sudah dapat memberikan komentar tentang peran matematika khususnya segiempat dalam kehidupan seharihari, misalnya penggunaan segiempat dalam membangun gedung, membuat alat-alat keperluan rumah tangga seperti serbet, taplak meja, dan sarung bantal.

Berkaitan dengan pengamatan observer terhadap keluwesan dalam menggali ide-ide matematis, strategi TTW ternyata dapat menuntun siswa menggali ide-ide matematisnya. Secara umum dari hasil pengamatan, pembelajaran matematika dengan strategi TTW dapat meningkatkan disposisi matematis siswa SMP, khususnya kemauan untuk menekuni tugas-tugas matematis, keluwesan dalam menggali ide-ide matematis dan mencoba metode-metode alternatif dalam menyelesaikan tugas.

Secara umum siswa yang memperoleh pembelajaran dengan strategi TTW memiliki kecenderungan yang positif terhadap disposisi matematis, misalnya minat untuk belajar bersama. Slavin (2008) menyatakan bahwa pembelajaran kooperatif pada setiap harinya memberikan kesempatan untuk terjadinya kontak personal yang intens di antara siswa dengan latar belakang ras berbeda. Lappan (2008) menyatakan, "Students need dispositions that will enable them to persevere in more-challenging problems, to take some responsibility for their own learning, and to develop good work habits in mathematics" Dibutuhkan kerja keras dan kesabaran guru dalam mengorganisasikan kelas agar siswa berhasil dalam melaksanakan aktivitas belajar mengajar, yang akan memberikan dampak pembelajaran berhasil mencapai tujuannya.

\section{KESIMPULAN DAN SARAN}

Penelitian ini telah memberikan hasil sebagai berikut, (i) Kemampuan menulis matematis siswa SMP yang memperoleh pembelajaran matematika dengan strategi TTW lebih baik daripada secara konvensional, (ii) Pemahaman matematis siswa SMP yang memperoleh pembelajaran matematika dengan strategi TTW lebih baik daripada secara konvensional, (iii) Kemampuan menulis matematis siswa SMP perempuan yang memperoleh pembelajaran matematika dengan strategi TTW lebih baik daripada siswa laki-laki, (iv) Pemahaman matematis siswa SMP perempuan yang memperoleh pembelajaran matematika dengan strategi TTW lebih baik daripada siswa laki-laki?, (v) Pembelajaran dengan strategi TTW dapat meningkatkan disposisi matematis siswa SMP.

Berdasarkan simpulan yang telah diuraikan, dapat dikemukakan saran-saran sebagai berikut, (i) Berdasarkan hasil penelitian diperoleh bahwa kemampuan menulis rangkuman siswa yang memperoleh pembelajaran dengan strategi TTW lebih baik dari pada secara konvensional, maka penerapan pembelajaran matematika dengan strategi TTW menjadi pilihan, (ii) Supaya pembelajaran dengan strategi TTW dapat berjalan dengan baik, sebaiknya: (a) guru menggali kemampuan siswa secara lebih mendalam sehingga tugas-tugas yang berkaitan dengan kegiatan think, talk, dan write yang dirancang sesuai dengan tujuan pembelajaran yang akan dicapai; (b) LAS (Lembar Aktivitas Siswa) dan LRS (Lembar Rangkuman Siswa) dirancang sedemikian rupa sehingga mendorong siswa dalam melakukan aktivitas menulis; (c) guru 
hendaknya membangun komunikasi yang baik dengan siswa, sehingga dalam memberikan bimbingan sesuai dengan tujuan pembelajaran dan kebutuhan siswa.

\section{REFERENSI}

Anderson, W. L. \& Krathwohl, R. D (Ed). (2001). A taxonomy for learning, and assessing. A revision of bloom's taxonomy of educational objectives. New York: Addision Wesley Longman, Inc.

Anku, S.E. (1996). Fostering students' disposition towards mathematics: A case from a Canadian University. Education, Vol. 116, 1996. Questia, Trusted Online Research. Diambil tanggal 28 September 2009, dari http://www.questia.com/

Annenberg Media. (1997-2009). Exploring Communication. Diambil tanggal 28 Oktober 2009, dari http://www.learner. org/.

Anonimous, (1999). Think, Talk, Write. Diambil tanggal 5 Maret 2008, dari http://www. mtsd.k12.wi.us/MTSD/District/ela-curriculum-03/writing/ think_t alk_write.html.

Ansari, B.I. (2003). Menumbuhkembangkan kemampuan pemahaman dan komunikasi matematik siswa SMU melalui stategi Think Talk Write (Disertasi). Bandung: UPI Bandung.

Arnawa, I M. (2008). Pengembangan perangkat pembelajaran berdasarkan strategi think-talkwrite untuk meningkatkan kualitas perkuliahan aljabar abstrak. Portal Penelitian Universitas Andalas. (On-line) Diambil tanggal 5 Maret 2008, dari http://lpua@unand.ac.id.

Brizendine, L. (2006). The female brain. Diambil pada tanggal 28 Oktober 2009, dari http://www.amazon.com/Female-Brain-Louann-Brizendine/dp/

Burchfield, P.C.; Jorgensen; McDowell; \& Rahn (1993). Writing in the mathematics curriculum. Diambil tanggal 1 Oktober 2009 dari http://www.woodrow.org/.

Burmana, D.D.(2008). Boys and girls brains are different. More on Modern Phrennology Diambil tanggal 6 Maret 2008, dari http://huehueteotl.wordpress.comboys-and girls-brains-aredifferent-more-on-modern-phrenoll.

Depdiknas. (2007). Panduan Lengkap KTSP. Yogjakarta: Diperbanyak oleh Pustaka Yustisia.

Folia, S. (2008). Pria dan wanita: Kita memang berbeda. Diambil tanggal 3 Maret 2009, dari http://tanah231.multiply.com/journal/

Huinker, D \& Laughlin, C. (1996). Talk you way into writing. In. P. C. Elliot and M.J. Kenney (Eds). Communication in Mathematics K-12 and Beyond. USA: NCTM.

Lappan, Glenda. (2008). Fostering a good mathematial disposition. Diambil tanggal 20 Agustus 2008, dari http://www.nctm.org/about/content. aspx?id=102.

Lee, K.P. (2004). A guide to writing mathematics. Diambil pada tanggal 1 Oktober 2009, dari http://ems.calumet.purdue.edu/mcss/kevinlee /mathwriting/writingman.pdf.

Mac.Gregor, M. (1999). Reading and writing mathematics. Children Reading Mathematics. Reston, Virginia: NCTM.

Masingila, J. \& Wisniowska, E. (1996). Developing and assessing mathematical understanding in calculus through writing. In P.C. Elliot and M.J. Kenney (Eds). Communication in Mathematics K-12 and Beyond, USA: NCTM.

Muijs, D. \& Reynolds, D. (2008). Effective teaching: Teori dan aplikasi. Terjemahan Helly Prajitno Soetjipto dan Sri Mulyantini Soetjipto. Yogyakarta: Pustaka Pelajar.

PGRI. (2006). Konsep gender. Diambil tanggal 20 Agustus 2008, dari http://www.scribd.com/docl.

Reiter, A. (1995). Writing a research paper in mathematics. Diambil tanggal 1 Oktober 2009, dari http://web.mit.edu/jrickert/www/mathadvice.

Rizal, A.K. (2008). Riset Kemampuan Matematika dalam Kajian perbedaan Gender. Diambil tanggal 22 Februari 2009, dari http://www. iptek.net.id. 
Slavin, R.G. (2008). Cooperative learning: Teori, riset, dan praktik. Terjemahan Nurulita. Bandung: Nusa Media.

Lappan, G \& Phillips, R.(2008). A designers speak: A curricullum developer lens on challenger in US Mathematics Education. Ohio: Michigan State University. http://www.educational designer.org/ed/volume1/issue3/article11/

Syaban, M.(2008). Menumbuhkembangkan daya matematis siswa. Diambil tanggal 11 Nopember 2009, dari http://educare.e.fleinpula.net 
Slavin, R.G. (2008). Cooperative learning: Teori, riset, dan praktik. Terjemahan Nurulita. Bandung: Nusa Media.

Lappan, G \& Phillips, R.(2008). A designers speak: A curricullum developer lens on challenger in US Mathematics Education. Ohio: Michigan State University. http://www.educational designer.org/ed/volume1/issue3/article11/

Syaban, M.(2008). Menumbuhkembangkan daya matematis siswa. Diambil tanggal 11 Nopember 2009, dari http://educare.e.fleinpula.net 